\title{
The nursing team's compliance with hand hygiene: motivational factors
}

\author{
Adesão da equipe de enfermagem à higienização das mãos: fatores motivacionais \\ Adhesión a la higiene de las manos: factores motivacionales
}

Annecy Tojeiro Giordani ${ }^{1}$, Helena Megumi Sonobe ${ }^{2}$, Gabriela Machado Ezaias ${ }^{3}$, Maria Apparecida Valério ${ }^{1}$, Denise de Andrade $^{2}$

This descriptive study aimed to verify factors which motivate compliance with hand hygiene on the part of the nursing team in a public hospital in Londrina, PR, Brazil, in 2012, and to propose strategies for improving this. A total of 135 nursing professionals participated, providing information on professional identification, continuing education, and the undertaking of hand hygiene. The motivation for complying with hand hygiene was linked to satisfaction in personal life for $45(33.3 \%)$ and to satisfaction in the work for 58 (42.9\%), as well as to autonomy for undertaking the nursing care, for 76 (56.3\%). The motivational factors which influence compliance with the practice of hand hygiene were: professional development/growth, interest in the work, flexibility for prioritizing the care actions, autonomy, and participation in the decisions. These must be taken into account in planning the continuing education, so as to improve compliance with hand hygiene, as well as the quality of the care provided.

Descriptors: Hand Disinfection; Asepsis; Motivation; Nursing, Team.

Estudo descritivo, com os objetivos de verificar fatores motivacionais à adesão na higienização das mãos por equipe de Enfermagem de hospital público de Londrina, PR, Brasil, em 2012, e de propor estratégias para sua melhoria. Participaram 135 profissionais de Enfermagem, que forneceram informações sobre identificação profissional, educação permanente e realização da higienização das mãos. A motivação para adesão à higiene das mãos esteve vinculada à satisfação na vida pessoal de 45 (33,3\%) e no trabalho de 58 (42,9\%), assim como a autonomia à realização dos cuidados de Enfermagem por 76 (56,3\%). Os fatores motivacionais influenciadores na adesão à prática de higienização das mãos foram: desenvolvimento/crescimento profissional, interesse pelo trabalho, flexibilidade para priorizar as ações de cuidado, autonomia e participação nas decisões. Estes devem ser considerados no planejamento da educação permanente para melhoria da adesão à higienização das mãos, bem como a qualidade da assistência prestada.

Descritores: Desinfecção das Mãos; Assepsia; Motivação; Equipe de Enfermagem.

Estudio descriptivo, cuyos objetivos fueron verificar factores motivacionales a la adhesión a la higiene de las manos por equipo de enfermería en hospital público de Londrina, PR, Brasil, en 2012, y proponer estrategias para su mejoría. Participaron 135 profesionales de enfermería, que fornecieron informaciones sobre identificación profesional, educación permanente y realización de la higiene de las manos. La motivación para adhesión a la higiene de las manos estuvo vinculada a la satisfacción en la vida personal, 45 (33,3\%); y en el trabajo, 58 (42,9\%); y autonomía en la realización de la atención de enfermería, 76 (56,3\%). Los factores motivacionales que fueron: desarrollo/crecimiento profesional, interés por el trabajo, flexibilidad para priorizar las acciones de cuidado, autonomía y participación en las decisiones. Estos deben ser considerados en el planeamiento de la educación permanente para mejoría de la adhesión a la higiene de las manos, así como la calidad de la asistencia prestada.

Descriptores: Desinfección de las Manos; Asepsia; Motivación; Grupo de Enfermería.

\footnotetext{
${ }^{1}$ Universidade Estadual do Norte do Paraná. Bandeirantes, PR, Brazil.

${ }^{2}$ Escola de Enfermagem de Ribeirão Preto, Universidade de São Paulo. Ribeirão Preto, SP, Brazil.

${ }^{3}$ Universidade Estadual de Londrina. Londrina, PR, Brazil.
}

Corresponding author: Annecy Tojeiro Giordani

Rodovia BR-369, Km 54, Vila Maria, CEP: 86360-000. Bandeirantes, PR, Brazil. E-mail: annecy@uenp.edu.br 


\section{Introduction}

International agencies such as the World Health Organization and the Pan-American Health Organization, as well as the Brazilian Health Surveillance Agency and health professionals in general, recognize hand hygiene as an aseptic procedure which is fundamental in healthcare and in the prevention and control of hospital infections. As this directly influences patient safety, greater compliance with hand hygiene is sought worldwide ${ }^{(1-3)}$.

Although there is evidence that correct hand hygiene is an indispensable measure for reducing the transmission of microorganisms by the hands, compliance with this practice remains low, with studies reporting rates below $60 \%$ in different healthcare contexts ${ }^{(4-6)}$. In one observational study on the undertaking of hand hygiene, compliance rates were below $40 \%$ among experienced health professionals. However, the self-evaluation made by these professionals overestimated their compliance. On the other hand, when hand hygiene was observed among trained nurses, compliance rates above $80 \%$ were ascertained ${ }^{(7)}$.

Considering the difficulties presented by health professionals in complying with hand hygiene, the World Health Organization proposes five points for undertaking it: before and after patient contacts, prior to undertaking aseptic procedures, after contact with surfaces close to the patient, and after the risk of exposure to body fluids. When the hands are visibly dirty, however, the process of hygienization must mandatorily be undertaken with soap and water ${ }^{(1-2)}$.

Among the individual and organizational characteristics, the professional performance in the practice of hand hygiene has a direct relationship to the professional's motivation, which can influence their behavior and decision-making, as well as their aspirations and their mobilization of efforts to comply with hand hygiene and persist when faced with possible difficulties ${ }^{(2,8)}$.
One of the best-known motivational theories in work is the Two-Factor Theory of the North American psychologist Frederick Herzberg, which emphasizes two factors: those of hygiene and motivation. The hygiene factors (extrinsic) refer to the physical conditions at work, the salary, the benefits, and the job security, among the variables which, when met, lead the individual not to feel dissatisfaction at work. The motivational factors (intrinsic) stimulate the worker to undertake her work activities, geared towards the work in itself and its undertaking, that is, they have a close relationship with the content of the position and with the nature of the tasks performed, consisting of personal and professional actualization and recognition; responsibility and development; professional growth and relationship with the position; autonomy; and creativity, challenging work and participation in decisions. Due to being intrinsic, they encourage individuals to become involved with the work, giving the best of themselves ${ }^{(9-13)}$.

In seeking to deepen knowledge regarding compliance with hand hygiene on the part of professionals from the nursing team, taking into account the motivational process in the work, we constructed an instrument for assessing the behavioral aspects involved in the practice, based in this motivational theory. Considering the hygiene and motivational factors in the nature of the work of Nursing, and the recommendations for hand hygiene, items were formulated for identifying these professionals' opinion regarding the influence of the above-mentioned factors in their compliance with this practice. The instrument initially contained 138 items, however, following face and content validation, adjustments were made to the instrument and it was finalized with 61 items.

The analysis regarding the hygiene factors related to the professional practice involves issues referring to salary and social benefits; interpersonal 
relationships; physical and environmental working conditions; safety at work; organizational policies and guidelines, and communication and status, in an understanding that these cannot motivate the professionals in undertaking the work, but influence their levels of dissatisfaction. Thus the hygiene factors related to the physical and environmental conditions are not able to modify how the individual undertakes her work ${ }^{(11)}$.

In order to undertake the various activities which make up the work, the motivational aspects focused upon by Herzberg can determine the conduct and behaviors of the Nursing professionals who, in their turn, influence the other members of the team. This can also be identified in relation to the practice of hand hygiene in hospitals and other health services, which requires a deepening of the knowledge regarding the behavioral aspects for their compliance, as identified by other authors ${ }^{(9,11-13)}$.

In this study, the objectives were: to verify the nursing team's motivational factors in their compliance with the practice of hand hygiene, and to propose strategies for improving this.

\section{Method}

This quantitative transversal study sought to describe the motivational factors involved in compliance with hand hygiene on the part of professionals of the nursing team in a general public state hospital, of mid-level complexity, in the city of Londrina in the North region of the Brazilian State of Paraná. This is a medium-sized institution with approximately 170 nursing professionals. Currently, the institution has 126 active beds allocated to the Unified Health System, distributed among Clinical and Surgical (adult and child) inpatient wards, Emergency
Room, and a small Surgical Center, which attends the need for elective operations in the municipality of Londrina and the surrounding region.

A total of 135 nursing professionals participated in the study, the inclusion criteria being: to have been a nursing professional for more than one year and to be active in the profession during the data collection period. Those who were absent, mainly due to health or holidays, were excluded. The data were collected by two researchers (one of whom belonged to the nursing team of the hospital studied) in the months of September and October 2012, during the professionals' shifts, following the institution's authorization. A room was set aside so that the participants could have calm and privacy for answering the instrument.

The data collection instrument encompassed information on professional identification, knowledge of the five points for undertaking hand hygiene, according to the World Health Organization, and participation in continuing education on this issue, as well as the hygiene and motivational factors, grounded in the Two-Factor Theory of Frederick Herzberg. Two domains were considered in constructing this instrument: Hygiene factors (extrinsic) and Motivational factors (intrinsic), each with six categories, all considering the professionals' opinion regarding the influence of these on compliance with the aseptic technique of hand hygiene. The domain of Hygiene factors was made up of six categories, namely: Salary and social benefits, with four questions; Relationship with managers, supervisors, and work colleagues, with seven items; Physical and environmental working conditions, with six items; Safety at work, with one item; Organizational policies and directives and communication, with five items, and Status, with one item. The six categories of the domain of Motivational factors are: Professional and personal actualization and 
recognition, with two items; Responsibility, with one item; Professional development, personal growth and content of the position, with three items; Autonomy, with one item; Creativity and challenging work, with two items; and Participation in the decisions, with one item, totaling 34 items.

Each item in the instrument had five response options on a Likert Scale, these being: (1) Strongly disagree, (2) Partially disagree, (3) neither agree nor disagree, (4) Partially agree, and (5) Strongly agree. This same numbering of the Likert items was used as codification for the options proposed in entering data into the database, that is, there was no link between minimum or maximum score as a parameter for valid responses for this study.

The process of content and face validation of the instrument was undertaken by 50 specialists (professionals and researchers from the area of infection control, and academics studying the TwoFactor Theory) in relation to the conceptual aspects, number of items, semantics and operational issues, and there being adjustment of the domains of: interpersonal relationships; professional recognition; personal growth; participation in decisions; and physical and environmental working conditions, in relation to the hygiene and motivational factors for compliance with hand hygiene, according to the theoretical framework proposed. Among those who undertook the validation, there was agreement of $83.5 \%$ for the items (motivational and hygiene factors), and $91.1 \%$ for content (compliance with hand hygiene). The Kappa coefficient was evaluated as moderate to excellent, as its internal consistency was $\alpha$ of 0.713 and 0.704 respectively, for the 135 participants in the study.

The variables were codified in a dictionary, with double keying in a database (spreadsheet) in Microsoft Excel XP, and were imported to the Statistical Package for the Social Sciences program, version 16.0.
Univariate exploratory analysis was undertaken simple frequencies and percentages, mean, median, and standard deviation - and these were presented in tables.

This study explored data for identification and professional practice regarding hand hygiene, as well as motivational factors such as Personal/Professional actualization and Recognition, Responsibility, Professional Development/Growth and relation with the position, Autonomy and Creativity, and challenging work.

The research project was approved by the Research Ethics Committee of the Ribeirão Preto School of Nursing (Opinion 184.732/2014), following, therefore, the ethical precepts of Resolution 466/12 of the Brazilian National Health Council.

\section{Results}

A total of 135 (100\%) nursing professionals, who had worked in the hospital area for over one year, participated in this study, these being: eight (5.9\%) auxiliary nurses; 96 (71.1\%) nursing technicians, and $31(22.9 \%)$ nurses. Of the total, $101(74.8 \%)$ were female, with salaries ranging from $R \$ 1,001.00$ to $\mathrm{R} \$ 3,000.00$ [US $\$ 452.35$ to US $\$ 1,355.69$ ]. Of the total participants, 104 (77\%) worked only in the hospital studied, while 112 (83\%) belonged to the MedicalSurgical Departments and Emergency Room, being 58 (43\%) and $54(40 \%)$ respectively.

In relation to training on hand hygiene and prevention and control of nosocomial infection in the last two years, of the 123 (91.1\%) participants, eight (5.9\%) could not correctly provide the five points stipulated by the World Health Organization for hand hygiene.

The motivational factors relating to compliance with hand hygiene are set out in Table 1. 
Table 1 - Distribution of the nursing professionals' motivational factors relating to compliance with hand hygiene. $(n=135)$

\begin{tabular}{|c|c|c|c|c|c|c|}
\hline Motivational factors & $\begin{array}{l}\text { Compliance } \\
\text { (\%) }\end{array}$ & Mean & Median & Maximum & Minimum & $\begin{array}{l}\text { Standard } \\
\text { deviation }\end{array}$ \\
\hline \multicolumn{7}{|l|}{ Personal/professional actualization and recognition } \\
\hline Satisfaction in personal life influences compliance with hand hygiene & $45(33.3)$ & 2.5 & 2.0 & 5.0 & 1.0 & 1.7 \\
\hline Satisfaction in one's work influences compliance with hand hygiene & $58(42.9)$ & 2.8 & 2.0 & 5.0 & 1.0 & 1.7 \\
\hline \multicolumn{7}{|l|}{ Responsability } \\
\hline $\begin{array}{l}\text { Taking on activities with greater responsibility influences the } \\
\text { undertaking of simpler tasks such as the practice of hand hygiene }\end{array}$ & $49(36.3)$ & 2.5 & 2.0 & 5.0 & 1.0 & 1.6 \\
\hline \multicolumn{7}{|l|}{ Professional development/growth and relation with the position } \\
\hline $\begin{array}{l}\text { Management's knowledge regarding the real situation of the care, and } \\
\text { participation in resolving conflicts influences compliance with hand } \\
\text { hygiene }\end{array}$ & $48(35.6)$ & 2.5 & 2.0 & 5.0 & 1.0 & 1.5 \\
\hline One's interest in the work influences compliance with hand hygiene & $95(70.4)$ & 3.7 & 4.0 & 5.0 & 1.0 & 1.6 \\
\hline $\begin{array}{l}\text { Having flexibility for prioritizing care actions influences compliance } \\
\text { with hand hygiene }\end{array}$ & $91(67.4)$ & 3.7 & 4.0 & 5.0 & 1.0 & 1.5 \\
\hline \multicolumn{7}{|l|}{ Autonomy } \\
\hline $\begin{array}{l}\text { Having autonomy in undertaking nursing care influences compliance } \\
\text { with hand hygiene }\end{array}$ & $76(56.3)$ & 3.2 & 4.0 & 5.0 & 1.0 & 1.7 \\
\hline \multicolumn{7}{|l|}{ Creativity and challenging work } \\
\hline $\begin{array}{l}\text { Having freedom to express one's ideas and opinions influences } \\
\text { compliance with hand hygiene }\end{array}$ & $40(29.6)$ & 2.3 & 1.0 & 5.0 & 1.0 & 1.6 \\
\hline $\begin{array}{l}\text { Challenging work requiring creativity influences compliance with hand } \\
\text { hygiene }\end{array}$ & $51(37.7)$ & 2.6 & 2.0 & 5.0 & 1.0 & 1.7 \\
\hline $\begin{array}{l}\text { In the acquiring of resources for hand hygiene, one's opinion should } \\
\text { be considered }\end{array}$ & $111(82.2)$ & 2.3 & 1.0 & 5.0 & 1.0 & 1.5 \\
\hline
\end{tabular}

Through the analysis of the data, it was possible to ascertain the tendency for agreement regarding the motivational factors involved in the participants' compliance with hand hygiene. The minimum and maximum values were established for comparison in relation to the means and medians, which indicated that the greater their values, the greater the influence of this motivational factor in compliance with hand hygiene. In addition, the standard deviation indicates the tendency for proximity to the mean, although this is influenced by responses with extreme tendencies in the instrument. As a result, the higher the standard deviation, the lower the homogeneity of responses regarding the influence of each motivational factor analyzed in compliance with hand hygiene.

On the other hand, the median was adopted for analysis regarding the values of lower, equal or higher responses, considering the median of the instrument used in this study.
Thus, in the motivational factor of personal/ professional actualization and recognition, there was agreement of $45(33.3 \%)$ regarding the influence of the item of satisfaction in personal life for compliance with the practice of hand hygiene, and of 58 (42.9\%) regarding the influence of the item of satisfaction in the work in the practice of hand hygiene, with means (2.5 and 2.8), the same maximum (5.0) and minimum (1.0) values, and median (2.0), with the standard deviation (1.7). We therefore identified greater agreement regarding the influence of the satisfaction in the personal life on compliance with hand hygiene, in relation to satisfaction in the work.

The item 'Taking on responsibility for activities with greater responsibility influences the undertaking of simpler tasks such as the practice of hand hygiene' received 49 (36.3\%) responses agreeing (totally or partially), reinforced by a mean (2.5) and standard deviation (1.6) relating to the category 
of responsibility, with a median (2.0). There was, therefore, less agreement regarding the influence of these motivational factors on compliance with hand hygiene.

In relation to the motivational factor of professional development/growth and relation with the position, there was total or partial agreement from only 48 (35.6\%) nursing professionals regarding the influence on compliance with hand hygiene, in relation to the item 'Management's knowledge regarding the real situation of the care, and participation in resolving conflicts influences compliance with hand hygiene' with a mean of 2.5; standard deviation of 1.5; and median of 2.0. There was, therefore, less agreement regarding the influence of this motivational factor on hand hygiene.

In this same motivational factor, on the other hand, the influence of the aspects of interest in the work and Having flexibility for prioritizing care actions influences compliance with hand hygiene obtained partial agreement, 95 (70.3\%) and total agreement from 91 (67.4\%), with the same means (3.7) and standard deviations (1.6 and 1.5); besides the median (4.0) respectively. These results indicated greater agreement regarding the influence of these motivational factors on compliance with hand hygiene.

Regarding the factor of autonomy, 76 (56.3\%) respondents partially or totally agreed that having autonomy in undertaking nursing care influences their compliance with hand hygiene, a result reinforced by the mean (3.2), median (4.0) and standard deviation (1.7). There was, therefore, greater agreement regarding the influence of these motivational factors on compliance with hand hygiene.

Regarding the factor of creativity and challenging work, the items of having freedom to express one's ideas and opinions and of having challenging work requiring creativity, as influences on hand hygiene, obtained 40 (29.6\%) and 51 (37.7\%) responses which totally or partially agreed, with means (2.3 and 2.6); medians (1.0 and 2.0) and standard deviations (1.6 and 1.7), respectively. As a result, there was less agreement regarding the influence of the item (having liberty to express oneself) and greater agreement regarding the influence of the item of challenging work on compliance with hand hygiene.

Finally, for 111 (82.3\%) nursing professionals, one's opinion should be taken into consideration when acquiring hand hygiene resources, which indicates that they value their participation in the decisions, with mean (2.3); median (1.0) and standard deviation (1.5). There was less agreement of this motivational factor with compliance with hand hygiene.

In summary, regarding the influence of the motivational factors on compliance with hand hygiene in Table 1, among the 10 items, only four had percentages above $50 \%$, namely: One's interest in the work (95=70.4\%); Having the flexibility to prioritize the care actions (91=67.4\%); Having autonomy in undertaking nursing care $(76=56 \%)$; and In acquiring resources for hand hygiene, one's opinion should be taken into account (111=82.8\%). The remaining six statements only achieved percentages below $43 \%$.

\section{Discussion}

The results obtained regarding the motivational factors of personal/professional actualization and recognition denote that each professional has a different perception relating to personal satisfaction and satisfaction in the work. While for some, the personal dimension includes the work, for others they are distinct. For many professionals, feeling oneself to be actualized encompasses being successful and influential, having opportunities to show one's competence, while their recognition and valuing depend on the opportunities offered, through the work, to achieve personal goals ${ }^{(14)}$.

The possibility for personal and professional actualization is an aspect which is fundamental to human motivation. In general, a person who dedicates themselves with efficiency to a specific labor activity expects to be recognized for their merits. Some authors argue that actualization is 
determined by the successful conclusion of a task or job, leading the individual to feel good in relation to the results of their own efforts, which is reflected in their personal life as much as their professional life. Intrapersonal life is influenced by many aspects of the job; feeling oneself to be recognized by the institution and by one's colleagues or hierarchical superiors is something desired by the majority. When this occurs, there is the perception of the possibility of growth and development at work and in one's personal life, that is to say, satisfaction from feeling oneself to be a necessary person, a feeling of belonging and being committed $^{(9,11-12,15)}$.

In nursing, the lack of recognition frequently causes dissatisfaction and demotivation, being reflected in the poor quality of care provided to the patients, and harm to the institution. In contrast, many Nursing professionals choose to work in specific sectors, taking into account their affinity, a fact which reasserts the importance of motivation in the exercising of the profession. Thus, many have good performance because they like what they do, and not because of what they represent to society or to the institution in which they work ${ }^{(10)}$.

For these individuals, undertaking high complexity procedures or undertaking hand hygiene have the same value, which presupposes the recognition of the importance of this aseptic technique in the health services. Therefore, even taking on greater responsibilities, this does not dispense them from practicing hand hygiene, as patient safety is paramount.

The feeling of responsibility arises from the undertaking of one's own work or of the work of other people. Facing new challenges and winning greater responsibility is motivating. Thus, one way of promoting motivation in nursing is to delegate authority and responsibility to the professionals through, for example, valuing communication and continuing education ${ }^{(15)}$.

Being a good professional is not linked to the type of management that one has, although it can stimulate and strengthen the individual's satisfaction in their work, which - consequently - keeps the level of dissatisfaction under control, although it does not change their behavior. The professionals recognize that their motivation for the work directly influences their compliance with hand hygiene, it being within this that what drives one or moves one to action is found ${ }^{(10)}$.

The work of the nurse and the team involves routine and mechanistic tasks, permeated by innumerable rules and norms of conduct. This suggests that in this profession, motivation may be a particularly challenging task, even for managers who wish to apply tools which are able to encourage their collaborators to improve the quality of their work. It follows that in an organizational environment in which interpersonal conflicts are natural, the way that these are managed becomes fundamental for the relationships, which influences the quality of the nursing professional's work, although it does not influence compliance with the practice of hand hygiene $\mathrm{e}^{(9)}$.

In general, people aspire to achieve certain positions and progress in their careers, to the extent that their work context offers them opportunities, including for professional improvement. The development of the career is an important aspect, and has a close relationship with motivation in the work $\mathrm{k}^{(15-}$ 16).

The possibility for professional growth occurs through the position or responsibilities which are given to the worker and fully accepted by him. Feeling that one has greater ability to exercise specific tasks makes one more confident and self-actualized, as one believes that the work contributes to one's growth, rather than being an obligation ${ }^{(17)}$.

Faced with challenging tasks, individuals tend to dedicate themselves fully not only to undertaking them, but to doing them as well as possible, using their creative strength to achieve productivity exceeding expectations $^{(18)}$.

Autonomy is possible in undertaking the routine 
work of nursing, respecting the skills and training of each member of the team. This aspect influences their compliance with hand hygiene, as it constitutes an important encouragement for undertaking tasks and, consequently, for maintaining one's professional motivation. Hierarchically speaking, however, the nurse can promote - or not - the possibility of members of her team exercising their autonomy in the work. Over time, this can increase the level of dissatisfaction, leading them to have a lower level of interest and dedication to the undertaking of the work, and, consequently, to their compliance with hand hygiene. Autonomy, with responsibilization, makes it possible for the worker to achieve better results, in a creative and innovative way. The results obtained are in accordance with this assertion.

An intrinsically motivated worker is self-led, and does not need somebody apart from himself to direct or control him. Obviously, the organization needs to provide him with conditions, credit and support for this to happen. In this way, through allowing relative autonomy in undertaking the work, there can be innovation, creativity and improvement of routines and tasks, avoiding frustration. In relation to the nursing professionals, their autonomy tends to be reflected in the quality of the health services, through use of their knowledge and skills for competent practice ${ }^{(11)}$.

In this way, individual aspirations which are in consonance with the institution's goals and objectives significantly improve the interpersonal relationships at work, and increase institutional commitment and autonomy, raising the levels of personal satisfaction. In Brazil however, nursing's autonomy is characterized as a process in construction, as in the hospital ambit, its work is extremely wearing, including as a result of the demands posed by the inflexible schedules and shiftwork. In the nurse's activities, in particular, there is frequently a variety, without autonomy or differentiation of well-defined functions, resulting from conflicts and role ambiguity ${ }^{(10,17)}$.

Having the freedom to express ideas and opinions, or a challenging job which requires creativity, do not influence compliance with hand hygiene. In the case of this practice, compliance is intrinsic to the professional. In this case, what he says to other people may be considered an external factor for the person who undertakes the work. The practice of hand hygiene dimensions the work, and the discourse is in the abstract plane. Thus, what one thinks in relation to the work to be undertaken is not considered concrete work and, therefore, does not constitute a model of action. In general, we select as models of professionals those who represent one who undertakes quality work, regardless of the hierarchy.

To feel pleasure because of the work that one undertakes, and because of one's reputation as an efficient worker, is a form of compensation, and attends the creative strength which exists inside each person. Thus, creativity has a close relationship to originality, to the capacity to invent, to create, to imagine and to innovate.

Challenging work, in general, requires creativity, bearing in mind the difficulties faced in undertaking it successfully. The problems which result must be faced actively if one is to seek solutions, which entails attitude, aptitude, and leadership with responsibility - which occur rarely if the individual is not motivated. As one develops professionally, the experience acquired makes one more mature and, as a consequence, causes one to give greater value to esteem and self-actualization at work and in one's personal life ${ }^{(15)}$.

Having the possibility to participate in decisions is related to people's compliance with hand hygiene, as it represents the quality of the equipment, materials and input for the maintenance of this practice, as the chemical products can cause the occurrence of skin reactions.

One way for managers to offer conditions such that the workers may feel motivated is to give them greater authority through participation in the organization's decision-making, a fact which favors greater involvement and development for everybody. As a democratic system par excellence, participative management seeks to encourage the workers' talents 
through believing in their capacity for self-management. Therefore, the workers' participation is fundamental in the decision-making, in resolving conflicts, and in raising their opinions regarding the work situations $^{(11,19-22)}$. The present study's results are also in conformity with these authors' assertions.

Dissatisfied workers show themselves to be disinclined to dedicating effort, knowledge and personal skills, compromising the provision of nursing care, which - predominantly in the hospital context involves a variety of care, requiring the undertaking of hand hygiene. It is necessary to ensure a relationship of exchange, as when an individual does not find a way of satisfying their expectations, or achieving their principal personal and professional goals, at work, they do not commit themselves to achieving better results.

Taking these motivational factors into account for improving compliance with hand hygiene, it is recommended that institutions should provide greater space for listening and dialogue with their nursing professionals, at all hierarchical levels. The knowledge of their ideas, requests and needs, in particular those related to self-esteem and self-actualization, allows the institution to reflect on and work on important issues linked to satisfaction and motivation in the work. The most significant results indicate that the factors of growth and development in careers/ profession, greater participation in the decisions, greater autonomy in undertaking the nursing care and encouragement for flexibility in prioritizing actions are fundamental to influencing compliance with hand hygiene.

\section{Final Considerations}

Herzberg's motivational factors provide support for the construction of the instrument for assessing the nursing professionals' opinion on the influence of these factors on their compliance with the practice of hand hygiene. Considering the set of results, we identify that the items of: interest in the work; flexibility for prioritizing care action; autonomy in undertaking the nursing care; and having one's opinion considered in the acquisition of resources for hand hygiene are those which most motivate the nursing professionals in relation to compliance with the practice of hand hygiene. In the view of these professionals, these variables are linked to the intrinsic aspect of the person who undertakes the work, and, consequently, influence her behavior in relation to compliance with hand hygiene. The other items studied present percentages which are of little significance. Nevertheless, all should be taken into account in the nursing professionals' work context in relation to improving compliance with hand hygiene.

The strategies proposed for improving compliance with hand hygiene must capitalise on the aspects discussed in this study which could strengthen motivation, which would consequently influence its practice. Continuing education, based in the professionals' participation, must be the principal route such that motivational factors may be valued and included so as to achieve better results, and the development both of individual and collective work.

This involves the construction of a new culture for the managers, in exercising a more humanized vision of the work. Taking the person into account, in relation to her expectations, satisfactions and dissatisfactions in the work is an exercise which certainly will lead to important changes, including in compliance with the practice of hand hygiene, in the institution in which this study was undertaken.

\section{Collaborations}

Giordani AT contributed in the collection, organization, analysis and interpretation of the data, and in the editing of the article. Sonobe HM assisted with the construction of the article and its revision. Andrade D provided advice and assisted with the article's construction and revision. Ezaias GM assisted in data collection and organization. Valério MA analyzed the data and assisted in their interpretation. 


\section{References}

1. World Health Organization (WHO). Guidelines on hand hygiene in health care - first global patient safety challenge clean care is safer care. Genebra: World Health Organization; 2009.

2. World Health Organization (WHO). A guide to the implementation of the WHO multimodal hand hygiene improvement strategy. Genebra: World Health Organization; 2009.

3. Agência Nacional de Vigilância Sanitária (ANVISA). Segurança do paciente. Higienização das mãos. Brasília: Ministério da Saúde; 2008.

4. Atif ML, Sadaoui F, Bezzaoucha A, Kaddache CA, Boukari R, Djelato S, et al. Reduction of nosocomial pneumonia using surveillance and targeted interventions in an Algerian neonatal intensive care unit. Infect Control Hosp Epidemiol. 2009; 30(7):712-3.

5. Homsted L. Guidelines for hand hygiene in healthcare settings. Fla Nurse. 2009; 57(1):12.

6. Hakko E, Rasa K, Karaman ID, Enunlu T, Cakmakci M. Low rate of compliance with hand hygiene before glove use. Am J Infect Control. 2011; 39(1):82-3.

7. Boyce JM. Hand hygiene compliance monitoring: current perspectives from the USA. J Hosp Infect. 2008; 70(supl. 1):2-7.

8. Bandura A, Azzi RG, Polydoro S. Teoria Social Cognitiva: conceitos básicos. Porto Alegre: Artmed; 2008.

9. Carvalho DR, Kalinke LP. Perfil do enfermeiro quanto à motivação profissional e suas necessidades de desenvolvimento. Bol Enferm. 2008; 2(1):82-95.

10. Azambuja EP, Pires DEP, Vaz MRC, Marziale MH. É possível produzir saúde no trabalho da enfermagem? Texto Contexto Enferm. 2010; 19(4):658-66.

11. Bergamini CW. Motivação nas organizações. 5aㅡ ed. São Paulo: Atlas; 2008.

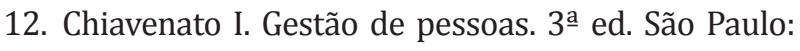
Campus; 2009.

13. Pilatti LA. Qualidade de vida no trabalho e a teoria dos dois fatores de Herzberg: possibilidadeslimite das organizações. In: Vilarta R, Gutierrez GL, organizadores. Qualidade de vida no ambiente corporativo. Campinas: IPES; 2008. p.51-62.

14. Vecina Neto G, Malik AM. Gestão em saúde. Rio de Janeiro: Guanabara Koogan; 2011.

15. Herzberg F. Work and the nature of man. $4^{\mathrm{a}}$ ed. Cleveland: The Work Plublishing Company; 1971.

16. Herzberg F, Mausner B, Snyderman BB. The motivation to work. $2^{\underline{a}}$ ed. New York: John Wiley; 1959.

17. Bezerra FD, Andrade MFC, Andrade JS, Vieira MJ, Pimentel D. Motivação da equipe e estratégias motivacionais adotadas pelo enfermeiro. Rev Bras Enferm. 2010; 63(1):33-7.

18. Carvalho MS, Palmeira EM, Mariano, MGH. Liderança baseada na motivação e desenvolvimento de pessoal como estratégia de competitividade das organizações. Obs Econ Latino-am. [Internet] 2012 [citado 2012 out 25]; (167):[cerca de 18 p]. Disponível em: http:// www.eumed.net/cursecon/ecolat/br/

19. Gugliotti AC, Oliveira, GB, Ribeiro CM, Almeida DE, Herculano LRM. Administração participativa como estímulo a motivação. Anuário Prod Inic Cient Disc. 2010; 13(17):289-98.

20. Motta FCP, Vasconcelos IFG. Teorias sobre motivação e liderança: da administração de recursos humanos à gestão de pessoas. In: Motta FCP, Vasconcelos IFG. Teoria geral da administração. São Paulo: Cengage Learning; 2008.

21. Gil ACO. O papel de motivador. In: Gil ACO. Gestão de pessoas. Enfoque nos papéis profissionais. São Paulo: Atlas; 2007. p. 201-19.

22. Celedônio RM, Jorge MSB, Santos DCM, Freitas CHA, Aquino FOTP. Políticas de educação permanente e formação em saúde: uma análise documental. Rev Rene. 2012; 13(5):1100-10. 